\begin{tabular}{|c|c|c|c|}
\hline 冓冓 & Received: 9 August 2018 & $\sqrt{\bar{e}}$ & Published: 31 October 2018 \\
\hline
\end{tabular}

\title{
TAZKIYATUN NAFS AS A STRENGTH BASE OF TEACHER PERSONALITY COMPETENCY
}

\author{
Abdul Ghofar, Uan Abubakar, Muhammad Azhar \\ E-mail: ${ }^{1}$ abdulghofar@gmail.com, ${ }^{2}$ usman.iainsolo@gmail.com, ${ }^{3}$ muazar@yahoo.com \\ ${ }^{1}$ Universitas Ahmad Dahlan, Yogyakarta, Indonesia \\ ${ }^{2}$ IAIN Surakarta, Surakarta, Indonesia \\ ${ }^{3}$ Universitas Muhammadiyah Yogyakarta, Yogyakarta, Indonesia
}

ABSTRACT
The teacher should have a steady, stable, adult, wise, and Keywords
authoritative personality competence, be an example for
learners, and have a noble character, but in reality, his Tazkiyatun nafs;
personality competence is still low and still far from the Personality;
personality that teachers should have. The authors offer an Teacher competence;
alternative solution with the Islamic psychology approach that Islamic education
is Tazkiyatun nafs that can be used as a basis of teacher
personality strengthening. This research uses qualitative
descriptive approach and literature or library research. The
essence of tazkiyatun nafs tends to talk about the soul (an-nafs).
It is a process of purification of the human soul from the
impurities, both visible dirt and inner dirt. Therefore, the notion
of tazkiyatun nafs is closely related to morals and psychology,
and in Islam, it serves as a pattern of human formation of good
character and cautious to Allah. In this study, the authors found
some of the following findings. First, the growth of one's
personality is influenced by factors from within that is the
integration of elements of aql (mind), qalb (heart), lust and
outside factors such as the process of interaction with the
environment. Second, the soul is very functional to one's
personality. A clean soul will produce good behavior while a
dirty soul will result in a low or weak personality.

\section{INTRODUCTION}

Philosophically education is a heritage of values from one generation to the next. With the inheritance of that value he can solve various problems faced life and at the same time he can build a civilization. Education is a very important aspect in supporting the country. When there was a second world war in 1945, Japan was totally defeated in the war against allied forces, Japan being a messy country. It is said that the first corrected is the teacher. Japan needs teachers to rebuild the country after it breaks apart (Ismail, 1995). Ten years later Japan can catch up with the world's leading countries. 
If it is observed throughout the history of the journey of human life, a nation that is concerned with education then the nation will be superior to civilization, when compared with a nation that is less concerned with education (Hamdzah \& Fatah Yasin, 2016). There are several factors that influence success in education. One of the important factors and even the most important factor is the teacher. Because teachers have the task of educating, teaching, training and directing learners. Teachers always get involved directly and face the students. Teachers become role models in the community especially in front of the students. Thus, the teacher acts as a human source and has a strategic position in education (Djamarah \& Zain, 2010).

A qualified teacher requires a certain qualification. As stated in Government Regulation No.19 of 2005 on National Education Standards, Article 28 states that "educators must have academic qualifications and competencies as learning agents, physically and mentally healthy, and have the ability to realize the goals of national education" (PP no. 19, 2005: 24). Such qualifications must be possessed by the teacher. All the qualifications are very important. Each other support and complement each other. Discussion of the teacher's qualifications is very wide. Therefore in the next discussion the author will limit to the qualification of competence. The teacher competency program becomes the absolute standard of teachers in improving the quality of teaching in order to achieve the goals of national education, as mandated by the constitution. However, in implementing the regulation has not been fully implemented by the government and society optimally.

In a dissertation by Imam Suraji entitled "Competence of Madrasah Teachers; Competence Analysis of Paedagogis, Personality and Social Teachers of Madrasah Ibtidaiyah Pekalongan". He revealed that "The low quality of professionalism of teachers is one of the causes of the lack of efforts to develop the competence of teachers by the parties concerned" (Suraji, 2010). As stated in the Law on Teachers and Lecturers (2010: 9), there are four competencies that must be attached with the teacher of pedagogic competence, personality competence, professional competence and social competence. Among the four competencies when compared to each other, personality competence is the most important competence, but it does not mean the other three types become unimportant. Because personality competence is the basis for three other types of competence (Mulyasa, 2013). Personality competence factors that determine whether he became a good educator and mentor for his students or vice versa (Djamarah \& Zain, 2010).

In the next discussion, the author will focus on the competence of the personality. Interest in personality competence, in addition to the above reasons also because the authors assume that the personality will bring a positive or negative image. Teachers should be used as role models. As role models, the teacher must have a personality that can be a profile and an idol, his whole life is a complete figure, that's the impression of the teacher as the ideal figure (Isjoni, 2009). Teachers who do bad deeds though little, will reduce his authority and charisma gradually melt from the identity of a teacher. Therefore, personality is a very sensitive issue. (Isjoni, Hermita, \& Samsudin, 2017). It is mentioned in the National Standard of Education, the explanation of Article 28 paragraph (3) point b, it is argued that what is meant by personality competence is a steady, stable, mature, wise and 
authoritative personality skill, be role model for learners, and have noble character (Mulyasa, 2008).

From this brief description, it can be understood that the problem in this research is the teacher who should have a steady, stable, adult, wise, and authoritative personality competence, be an example for learners, and have noble character, but in reality his personality competence is still low and still far away with the personality that teachers should have. In this article, the author offers an alternative solution with the Islamic psychological approach that "Tazkiyatun Nafs" or "Purification of the Soul" can be used as the basis of teacher personality strengthening. Tazkiyatun nafs essence tends to talk about the soul (an-nafs). There are four terms related to an-nafs namely al-qalb, ar-ruh, an-nafs, and al-aql. Al-Ghazali interpret tazkiyatun nafs is a process of purification of the human soul from the dirt, both dirt and inner dirt (Neha, 1995).Thus, anyone who expects Allah and the end, must pay attention to the cleanliness of his soul. Allah also makes the happiness of a servant dependent on tazkiyatun nafs.

This research uses qualitative descriptive approach (Sukmadinata, 2012), and library research as the type of this research. The literature review materials can be drawn from various sources such as textbooks, research journals, dissertations, theses, research reports, government publications, papers, seminar reports, scientific discussions and global literature contained in the internet. Research methods include data sources, data collection, and data analysis. This research includes literature research therefore the technique used in data collection is the literary data that is coherent library materials with the object of discussion in question (Suharsimi, 2013). The data contained in the literature is collected and processed by: a) Editing, i.e. re-examination of data obtained primarily in terms of completeness, clarity of meaning and harmony of meaning between one with another. b) Organizing, i.e. organizing the data obtained with the necessary framework. c) The findings of research that is doing further analysis of the results of organizing data by using rules, theories and methods that have been determined so that obtained a certain conclusion that is the result of the answer from the formulation of the problem. Analysis of data that the author takes is content analysis with the framework of inductive thinking and the discussion is done descriptively-analysis.

\section{RESULTS AND DISCUSSION Teacher Competence}

The teacher in Javanese is pointing to a person who must digugu (trusted) and ditiru (imitated) by all students and even the community. Digugu means everything that is delivered by the teachers always trusted and believed as the truth by all students. While ditiru means a teacher must be role model for all students. Traditionally the teacher is a person who stands in front of the class to convey science (Sardiman, 2006). Teachers are positions or professions that require special education that cannot be replaced by others. A qualified teacher requires a certain qualification. As stated in regulation No.19 of 2005 on National Education Standards (Presiden RI, 2005). 
Some teacher definitions according to some experts:

1) The teacher is anyone who is responsible for the development of the students. $\mathrm{He}$ can be interpreted also the second most responsible for the students after the parents (Tafsir, 1992).

2) According to Mulyasa, the term teacher is the educator who becomes the leader, role model and identification of the students and the environment, therefore the teacher must have certain personal quality standards that include responsibility, dignity, independence and discipline (Mulyasa, 2013).

3) According to Mc. Leod was quoted as saying by Trianto that teacher is "A person whose occupation is teaching others, that is, one whose main task is to teach." (Syah, 1997).

From these explanations it can be understood that; 1) a teacher is a profession that requires special education with certain personal quality standards that cannot be replaced by others, 2) the printing of real leaders for the community in the future, 3 ) responsible for the development and 4) the role model and identification of the learners and their environment, in charge of educating, teaching, guiding, directing, training, assessing and evaluating learners in physical and mental development. The competence of teachers is a combination of personal, scientific, technological, social and spiritual skills that in turn form the competence of teacher professional standards, which include mastery of materials, understanding of learners, educational learning, personal development, and professionalism (Mulyasa, 2008).

In another sense, competence is a unified whole that describes the potential, knowledge, skills, and attitudes assessed in relation to a particular profession with regard to parts that can be actualized and manifested in the form of action or performance to run a particular profession (Asmani, 2009). Ability or quality has a logical consequence that, a teacher is required to really have the provision of knowledge and skills adequate and in accordance with the profession, so he can perform the tasks as well as possible. Awareness of competence also requires heavy responsibility for the teachers themselves. The teacher must have the courage to face the challenges in his duties and environment, which will affect his personal development. In Law number 14 of 2005 article 10 states that: "teachers must have pedagogical competence, personality competence, social competence, and professional competence.

"The four competencies are described in detail by Trianto and the Quarter Point as follows: First, Pedagogic Competence is the ability of teachers in managing learning, such as the ability to plan and implement learning, the ability to conduct learning evaluation. Second, Personality Competency is a steady, stable, mature, wise, authoritative personality capability, an example for learners, and noble character. Third, Social Competence is the ability of educators as part of the community to communicate and get along effectively with learners, education personnel, parents of learners, and the surrounding community. Fourth, Professional Competence is the ability of mastery of learning materials in a broad and deep that enables it to guide learners (Trianto \& Triwulan, 2007).

Without ignoring the factors of other competencies, the most important factor for a teacher is the competence of his personality, the personality that determines him to be a 
good educator and coach for his students. The real personality is abstract, hard to see and know in real terms, which known as the appearance or the scars in all aspects and aspects of life. For example, in the behavior, speech, how to get along, dress, and face any problems both light and heavy. (Djamarah \& Zain, 2010). In a simple sense, personality means the intrinsic attitudes of the individual which is reflected in his attitudes and deeds that distinguish him from others (Syah, 1997). According to Jam'an Satori, in Fachruddin Saudagar; Ali Idrus (2011), what is meant by the competence of personality is the competence related to the behavior of the teacher itself who later must have noble values so that emanated in everyday behavior (Saudagar \& Idrus, 2011). Having a healthy personality and intact, with characteristics as required in the formulation of personality competencies above can be viewed as a starting point for someone to become a successful teacher. Because in the context of teacher tasks, the pedagogical, professional and social competence of a teacher will essentially be sourced and dependent and interacting with the student will be largely determined by the personality characteristics of the teacher in question.

\section{Personality}

From the literature reviewed, it was found that the term personality in several languages is called personality (English); persoonlijkheid (Netherlands); personnalité (France); personalità (Italy); persönlichkeit (Germany); and personalidad (Spayol) (Simpson, 1979). In Indonesian the word personality is defined as an intrinsic trait which is reflected in the attitude of a person or a nation that distinguishes itself from other people or other nations (Adz-Dzakiey, 2007). Some definitions on personality by experts are as follows:

a. Personality is a distinctive pattern of thoughts, feelings, and behaviors that distinguish one person from another and do not change across time and situations (Phares) (Alwisol, 2009).

b. Alport as quoted by Mujib defines personality as a dynamic organization within the individual about the psycho-physical system that determines its unique alignment to the environment (Mujib, 1999).

c. The real personality is abstract (ma'nawi), difficult to see or to know in real terms, which can be known is the appearance or the scars in all aspects and aspects of life (Djamarah \& Zain, 2010).

d. Based on the description of the various definitions above, there are several equations that characterize the definition of personality: Personality, derived from the Latin word, ie persona meaning mask. A mask is a face cover that is often used by stage performers who mean to describe a person's behaviour, character or personality. Personality is general: Personality refers to the general nature of a person, thoughts, activities, and feelings that affect his overall behavior. Personality is typical: personality is used to explain the nature of the individual that differentiates him from others. Personality is a dynamic organization within the individual about the psycho-physical system (mind, heart and lust) that determines its unique alignment to the environment. 
e. Personality long-term: personality is used to describe the nature of the individuals who are durable, not easily changed throughout life. If the change is usually gradual and transient or as a result of responding to an extraordinary event.

Furthermore, besides the personality mentioned above, there are some titles that have similar meanings or form some equations, such as Moral, which means the nature embedded in the soul that gives rise to easy deeds without the need for thought and consideration. According to Adamu Zakiyu Ubale \& Abdul Hakim Abdullah, man consists of three elements namely body (Jism), soul (nafs) and spirit (Ruh) (Ubale \& Abdullah, 2015). He further explained that all requirements (body, soul and spirit) are interrelated and can never be separated from each other. In Islam, the determination of the structure of personality cannot be separated from the discussion of human substance, because with the discussion of the substance can be known the nature and dynamics of the process. Human substance consists of bodies and spirits. Each of these different aspects in principle needs each other. Selfless body is a dead substance, a spirit without a body cannot be actualized. Because of mutual need, needed a synergy between the two, which in Islamic Psychology terminology is called the nafs. Thus, Islamic fundamental values of personality refer more to the human substance consisting of physical substance, spiritual substance and nafs substance. These three substances are strictly distinguishable, but certainly not inseparable.

Psychic is a psychological phenomenon that can be witnessed and indulged, if it has accumulated in the form of behavior, either intentional or reflex movements. The positive thing of the psychic is affection and kindness, whereas the negative will be found on the nature of emotion, anger, envy, and so on. Nafs has elements: 1) Lust, i.e. impulse (lust) to something that is low, immediate and do not heed moral values. 2) Qalb or heart, according to Ibn Araby is a body organ that produces true knowledge, a thorough intuition, knowing Allah SWT. In addition, it is a divine mystery. In short, the heart is the organ part of everything that is qualified to know the invisible science. It is this qalb nature which is then referred to as the ratio qalbani that exists in the nafs, as the selfish self-incarnation, ie the place of actualizing all the potential that exists in qalb in the form of spiritual power to impact on the action or behavior. Thus, qalb is the spiritual part of man. It exists, but its existence can only be felt, like a breezy wind breeze. The equivalence of spiritual gestures is similar to the existence of revelation and inspiration, so the truth for those who are open and exposed to the veil behind itself is the same as the truth of revelation. 3) Aqal (intelligent), the Arabic dictionaries provide aql (literally) meaning with al-imsak, alribath, al-hijr, al-nahy and man'u (Taufiq Pasiak, 2012). The intelligent person (al-'aaqil) is the one who restricts himself and rejects the desires of his lust (Balawi, 2007). Thus, it can be understood that mind is the potential possessed human as a tool for thinking to distinguish what is right and what is wrong. The three components are nafs; heart, mind and lust integrate to realize a behavior.

Factors that affect personality. Syamsu Yusuf (2010) explains that the development of one's personality is influenced by two factors namely heredity and environmental factors. Heredity factors include body shape, blood, and inherited traits from parents. While environmental factors include the home, school and community. 


\section{a. Heredity factor.}

One of the individual differences is the background of individual heredity. Heredity can be interpreted as the inheritance or biological displacement of individual characteristics of both parents. Heredity or innate is all the characteristics, traits, potential and ability possessed by the individual because of his birth. The characteristics, attributes and abilities are brought by the individual from his birth and received as a descendant of both parents (Sukmadinata, 2004). Thus from the description it can be understood that this heredity factor becomes an important factor in growth and development, as the inheritance or biological displacement of individual characteristics. This heredity factor can not be engineered, because heredity is a factor derived directly by parents.

b. Environmental factor

M. Dalyono (2010) states that people often interpret the environment narrowly, as if the environment is just the natural world outside of human beings or individuals. This environment actually includes all the material and stimuli inside and outside the individual self, both physiological, psychological and socio-cultural. Thus, the environment can be physiologically and culturally interpreted.

Factors that have more impacts on the personality of a person have triggered different opinion of the experts. In this case, there are three streams at least:

a. Nativism.

Nativism comes from the word natus = born; nativist $=$ the innate nature of which the human mind (human child) has been born from birth has brought about something called potential (basic) power (Suryabrata, 1984). This nativism based on the leibnitzian tradition that emphasizes the ability in each person, so that environmental factors, including educational factors, less influence on personality. The flow of Nativism views heredity as a determinant of personality. Heredity is the totality of character traits that are under or transferred from the parents to the offspring. This genetic transfer is a function of chromosomes and genes. The chromosome is a cell part that contains descendants, a dark-colored body within the nucleus of the elementary cell. Genes are any hypothetical particles located along the chromosomes that are elementary units of offspring or immortality.

b. The Empiricism, contrary to the notion of the flow of Nativism. Empiricism (empiric meaning, experience), and also called the flow of environmentalism, which is a flow that focuses his view on the role of the environment as the cause of the emergence of personality (Suryabrata, 1984). This flow does not recognize the innate or potential personality that is under human since birth. In other words that the son of man was born in a holy state in the sense of a clean child brings nothing. Therefore, the flow is the view that the personality of a person great influence on environmental factors. The pioneer of Empiricism is an English philosopher named John Locke (1704-1932) who developed the "Tabula Rasa" theory, the child born in the world like a clean white paper (Kalisman, Silberberg, \& Markram, 2005). Empirical experience gained from the environment will have a major influence in determining the development of human personality. 
c. Convergence

Convergence comes from a convergent word, meaning it is toward a meeting point. This flow holds that the personality traits are determined by the foundation (talents, descendants) and the environment, both of which play an important role. Convergence as a theoretical flow, emphasizing the relationship between innate factors and experience factors gained from the environment. That means that this Convergence flow, bringing together theories of Nativism and Empiricism. Convergence pioneer is William Stern (1871-1939), a German education expert who thinks that a child is. (O'Grady, 1999).

In the Islamic perspective, the starting point of the distinction of each stream (Nativism, Empiricism, and Convergence) lies in the factors affecting human development. Whether human development is determined by innate factors (nativism) or by educational and environmental factors (empiricism), or both are mutually influential (Convergence).

In this regard, Islam as a comprehensive religion has a different view with nativism, empiricism, and convergence. Islam presents the theory of fithrah (positive potential) as the basis of human development. According to the concept of Islam, basic ability may be paralleled by the term fitrah. Etymologically, the word fitrah means the origin of events, innate, identity, and human instinct (Shihab, 1992). Furthermore, he said that fitrah is the basic ability factor of human development that is born from birth which is centered on the basic potential to develop (Shihab, 1992). The basic potential is thoroughly developed (integral) that moves all its mechanically mutually influential aspects toward one another. According to the aspects of nature consists of basic components (talent, instinct, lust, character, heredity, and intuition) that are dynamic and responsive to the influence of the surrounding environment, including the influence of education.

According to the concept of Islam, fitrah in relation to the environment when affecting human development is not neutral, as is the view of empiricism that considers the newborn as a clean sacred of innate (potential) good and bad. For Islam, man is born with a nature with a permanent tendency. Fitrah will interact actively and dynamically with the environment in the process of human development.

Besides the explanation above, human has two substances namely the spiritual aspect and physical aspects. The integration between the spiritual aspect and the physical aspect produce the nafs or soul as an intermediary (psycho and physical) to carry out activities in life. The aspect of the nafs itself has three components: mind, lust and heart or qalb (Neha, 1995). Nafs that has the components of the heart, mind and lust functioned to move and encourage the human self to do several things, namely as follows:

a) Al-Qalb / heart

Al-Qalb comes from the word qalaba which means to change, move, or reverse. Qalaba undergoes several form changes such as inqalaba and qallaba, but the meaning is still the same. Qalb according to the description of al-Ghazali can be connoted in two meanings are: 1) Meat in the form of a hemisphere that is on the left side of the chest containing blackish red blood and is the source of the spirit of life. In this sense, it is a gift of Allah SWT which is given to human. It has a very important position and function, 
because the heart acts as a driving and controlling the rest of the body. If the heart is good, then the other limbs will also be good, whereas if his heart is ugly, then the other members of the body will follow the ugly. In addition, this heart is a physical-shaped heart. This is based on a hadith narrated by Imam Bukhari and Muslim that reads:

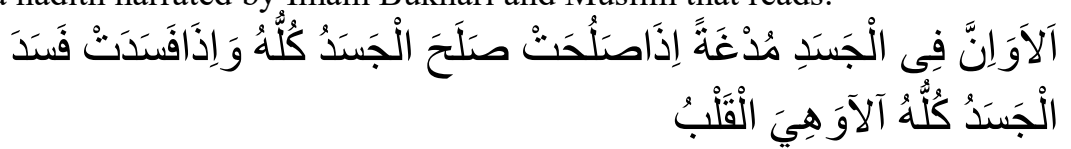

"Remember that in the body there is a piece of meat. If it is good, then the body is entirely and if it is damaged, then the body is completely destroyed. Remember that piece of meat is the heart "(Zumroh, 201 1: 11). (Shakhih Bukhari no.50: http://www.Shamela.ws).

The nature of tenderness (lathifah), Rabbaniyyah, ruhaniyyah, which adheres to the heart of jisim, he has the same dependence as dependent on the soul with the body, or as it depends on the nature of the thing that it is. Lathifah itself in this case is the essence of human beings who have the ability to understand, know, dialogue, potentially rewarded or tortured (al-Ghazali, t.th : 4). He is able to understand, perceive, and cure. For example, feeling sad and happy.

b) Al-aql

First sense: sometimes it is aimed and intended at the knowledge of the nature of all circumstances. So mind is like the nature of science that takes place in the heart.The second understanding is that which acquires that knowledge. That is the heart, which is the subtle (lathifah). Sometimes reason is also aimed and intended: the nature of the learned, and sometimes aimed and intended: the place of knowledge, that which knows (Imam AlGhazali , 1994 : 898). Etymologically mind has the meaning of holding (Al-Imsak), bonding (Al-Ribath), holding (Al-Hajr), forbidding (Al-Nahy), and preventing (Al-Man'u). Based on the meaning of language then the so-called Person of intelligence is a person who can hold and bind his passions. Intellect is defined as the energy that is able to acquire, store and release knowledge. Psychologically mind has a function of cognition (creativity). Cognition is a general concept that encompasses all forms of cognitive experience, such as: observing, seeing, caring, thinking, imagining, thinking, predicting, considering, guessing and judging (Mujib \& Mudzakir, 2003).

c) Nafs/Lust

Imam Ghazali, (t.th: 4) classifies lust to two means. The first sense of the nafs is combination between power of anger and passion for man. The second meaning of the nafs is lathifah (the subtle). This is the essence of man that distinguishes him from lust. The first term of the nafs according to the Sufis is lust, which is the subject that gathers the despicable properties of man, so they say that we must fight lust and break it (Al-Ghazali, 1992: 584).

Amiruddin (2005: 35) explains that if a person wants to be a lucky man, he should love to cleanse the soul and try hard to keep away from things that will pollute it. To obtain a holy soul can be pursued by the following methods: 


\section{a. Muhasabatunnafs}

Muhasabatunnafs means to self-correct. When we feel this soul is dirty, immediately clean with repentance and the improvement of godly charities. The Word of Allah in Surah al-Hashr, 59: 18:

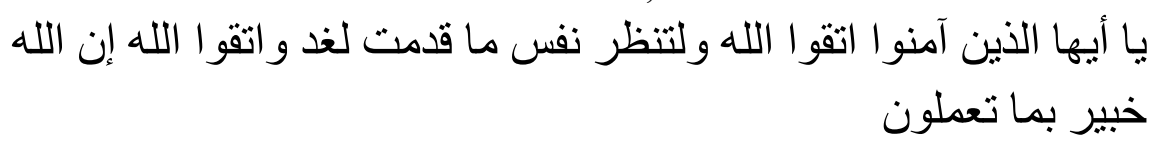

"O ye who believe! Be fearful of Allah, and let everyone see what He has done for tomorrow; and fear Allah, Allah knoweth all that ye do."

b. Taubat

Taubat means self-improvement. Taubat is a follow-up of selfintrospection. When we carry out self-introspection, of course we will find shortcomings. If we are able to improve ourselves and not repeat again, we have done repentance. The Word of Allah in surah of Ali Imron, 3: 133:

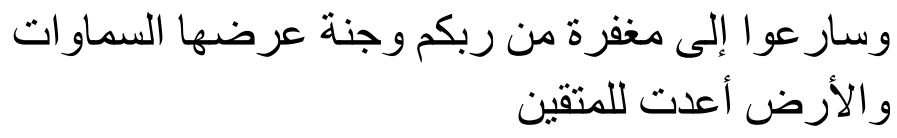

"And hasten to the forgiveness of your Lord and to the heavens as vast as the heavens and the earth provided to the righteous"

c. Interaction with godly people

Humans are social beings. Thus, the environment has an important role in the formation of character and personality. If we want to have a clean soul, associate with those whose souls are clean. The word of God in Surat alKahf, 18: 28:

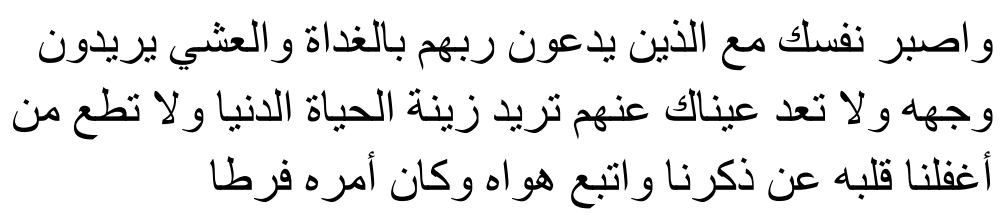

"And be patient with those who call on their Lord morning and evening by wishing His pleasure; and let not your eyes turn away from them (for) expecting the jewelry of this world; and do not follow those whose hearts We have neglected from remembering"

d. Prayer

Praying with humility is a mirror of a submissive servant, obedient only to God, surrendering his whole life to God. Allah SWT. Speaks in surah AlMu'min, 40: 60:

"And your Lord said:" Pray to Me, I will permit you, for those who arrogate from My worship will go to Hell in a despicable state. " 


\section{CONCLUSION}

Personality competence is the most urgent competency of the four competencies that must be attached to the teacher of pedagogic competence, personality competence, professional competence and social competence. Man has structure: body, spirit and soul. The soul is the inner side of man; it is like a very large room and inside there are parts as its sub system, which consists of elements of aql (mind), qalb (heart), and lust. The growth of one's personality is influenced by internal factors such as the integration of the elements of 'aql (mind), qalb (heart), and lust, and external factors, namely the process of interaction with the environment. Function of the soul or nafs is the command center of all human activities, as well as a driving force that drives all kinds of gestures and human behavior. Good or evil deeds, actions that are beneficial or harmful, they are driven by the nafs / soul. In detail the functions of the soul (aql / sense, qalb / heart and lust).

The third person subsystem (reason, heart and lust) is normal, and then his behavior is proportional. People who follow their minds are more rational but his lives tend to be hollow, people who use their hearts more, their lives are calm even though sometimes not rational, people who follow their own lust tend to consumptive, hedonic, destructed for himself and others.

Tazkiyatun nafs means to sanctify the soul or the self from the works of shirk and its branches (riya, arrogance, etc.), inculcate the values of the monotheism and its branches, and apply the deeds according to the names of Allah accompanied by worship to Allah, and follow the sunnah of the Messenger of Allah. Tazkiyatun nafs has a role in strengthening the personality. Because through tazkiyatun nafs, the soul becomes holy, the holy soul means its personality is healthy or strong. If his personality is healthy or strong then he will tend to produce good behavior. In other words, that through tazkiyatun nafs can strengthen one's personality.

\section{REFERENCES}

Adz-Dzakiey, H. B. (2007). Psikologi Kenabian; Menghidupakan potensi Kepribadian kenabian dalam diri. Yogyakarta: Beranda Publishing.

Alwisol. (2009). Psikologi Kepribadian. Malang: UMM Press.

Asmani, J. ma'ruf. (2009). 7 Kompetensi Guru Menyenangkan dan Profesional. Yogyakarta: Power Books (IHDINA).

Balawi, A.-Z. (2007). Pendidikan Remaja antara Islam dan Ilmu Jiwa. In Pendidikan Remaja antara Islam dan Ilmu Jiwa. https://doi.org/10.1007/s10854-015-3463-8

Dalyono. (2010). Bab I-lii. Psikologi Pendidikan. https://doi.org/10.1016/j.ceramint.2017.09.172

Djamarah, S. B., \& Zain, A. (2010). Guru dan Anak Didik dalam Interaksi Edukatif Suatu Pendekatan Teoritis Psikologis. Jakarta:Rineka Cipta.

Hamdzah, H., \& Fatah Yasin, R. F. (2016). Child Abuse in Malaysia: An Overview from 
Islamic Perspective. Journal of Global Business and Social Entrepreneurship.

Isjoni, I. (2009). Guru sebagai Motivator Perubahan. Yogyakarta: Pustaka Pelajar.

Isjoni, I., Hermita, N., \& Samsudin, A. (2017). Why should history teachers develop their pedagogical competences? Advanced Science Letters. https://doi.org/10.1166/asl.2017.10189

Ismail, F. (1995). Islam, Politics and Ideology in Indonesia: A Study of the Process of Muslim Acceptance of the Pancasila. Unpublised.

Kalisman, N., Silberberg, G., \& Markram, H. (2005). The neocortical microcircuit as a tabula rasa. Proceedings of the National Academy of Sciences. https://doi.org/10.1073/pnas.0407088102

Mujib, A. (1999). Fitrah dan Kepribadian Islam; Sebuah Pendekatan Psikologis (1st ed.). Jakarta: Darul Falah.

Mujib, A., \& Mudzakir, Y. (2003). Nuansa-nuansa Psikologi Islam. Jakarta: PT.Raja Grafindo Persada.

Mulyasa, E. (2008). Implementasi kurikulum tingkat satuan pendidikan: kemandirian guru dan kepala sekolah. Jogjakarta: Bumi Aksara.

Mulyasa, E. (2013). Uji kompetensi dan Penilaian Kinerja guru. Bandung: PT Remaja Rosdakarya.

Neha, A. (1995). Implementasi Tazkiyah al Nafs Pada Inabah Yayasan Serba Bakti Pondok Pesantren Suryalaya Tasikmalaya Jawa Barat. PP Suryalaya-Tasikmalaya.

O'Grady, W. (1999). Toward a New Nativism. Studies in Second Language Acquisition. https://doi.org/10.1017/S0272263199004040

Presiden RI. Peraturan pemerintah Republik Indonesia Nomor 19 tahun 2005 tentang standar nasional pendidikan, Peraturan pemerintah Republik Indonesia § (2005). https://doi.org/10.1126/science. 1173146

Sardiman, A. . (2006). Interaksi dan Motivasi Belajar-Mengajar. In Interaksi dan Motivasi Belajar-Mengajar. https://doi.org/10.1140/epjd/e2009-00307-2

Saudagar, F., \& Idrus, A. (2011). Pengembangan Profesionalitas Guru. Jakarta: Gaung Pesada Press.

Shihab, M. (1992). Membumikan Al-Quran. Bandung: Mizan.

Simpson, D. P. (1979). Cassell's Latin Dictionary. Medical and Veterinary Entomology. https://doi.org/10.1006/jhev.2000.0422

Suharsimi, A. (2013). Metodologi penelitian. bumi aksara.

Sukmadinata, N. S. (2004). Landasan Psikologi Proses Pendidikan. PT. Remaja Rosdakarya.

Sukmadinata, N. S. (2012). Metode Penelitian Pendidikan. Remaja Rosdakarya. https://doi.org/10.1016/S0969-4765(04)00066-9

Suraji, I. (2010). Kompetensi Guru Madrasah: Analisis Kompetensi Pedagogik, Kepribadian, dan Sosial Guru Madrasah Ibtidaiyah di Kota Pekalongan. Universitas Islam Negeri Sunan Kalijaga.

Suryabrata, S. (1984). Psikologi Perkembangan. Yogyakarta: Rake Press.

Syah, M. (1997). Psikologi Pendidikan dengan Pendakatan Baru. Bandung: Remaja Rosdakarya. 
IJISH, Volume 1, Number 2, October 2018: 128-140

Tafsir, A. (1992). Ilmu Pendidikan dalam Perspektif Islam. Jurnal Tasamuh. https://doi.org/http://dx.doi.org/10.21111/at-tadib.v8i2.502

Taufiq Pasiak. (2012). Antara 'Tuhan Empirik' dan Kesehatan Spiritual. In book section. https://doi.org/10.1109/ICASSP.2011.5946440

Trianto, \& Triwulan, T. (2007). Sertifikasi Guru dan Upaya Peningkatan Kualifikasi. Jakarta: Prestasi Pustaka.

Ubale, A. Z., \& Abdullah, A. H. (2015). The Effects Of Spirituality In Shaping The Human Behaviour (An Islamic Perspective). International Journal of Academic Research in Business and Social Sciences. https://doi.org/10.6007/IJARBSS/v5-i9/1793

Yusuf, S. (2010). Psikologi Perkembangan Anak dan Remaja. In PT. Remaja Rosdakarya. https://doi.org/10.1038/clpt.2011.83 